\title{
BABY BOOMS AND DRUG BUSTS: TRENDS IN YOUTH DRUG USE IN THE UNITED STATES, 1975-2000*
}

\author{
Mireille Jacobson
}

Are there agglomeration economies in crime? The positive correlation between city size and crime rates is well-known. This paper establishes a positive relationship between youth cohort size and marijuana use rates. It further demonstrates a negative association between youth cohort size and marijuana prices, youth drug possession arrest rates, and both overall and youth sales arrest rates. Cohort size affects demand by lowering possession arrest probabilities, but this factor explains less than 10 percent of the relationship. The main effect shown here, accounting for at least a quarter of the relationship, is on the supply of marijuana. Larger youth cohorts yield thicker drug markets that, through lower sales arrest risk and informational economies, generate cost-savings in drug distribution.

\section{INTRODUCTION}

Observers of social phenomena point to the 1960s as a turning point in American history. Between 1960 and 1980, as the baby boomers reached adolescence, rates of teen substance use, criminal involvement, suicide, and murder all rose considerably [Easterlin 1978; Gruber 2001]. Demographers, most notably Easterlin, have suggested that the increase in youth cohort size over this period is itself partly responsible for these trends. Larger youth cohorts put a strain on existing resources and institutions, and competition for these resources hinders both life opportunities and social development. Since the 1980s, however, most youth social indicators, such as teen birthrates, suicide rates, and violent crime rates, have not exhibited the trends that Easterlin's hypothesis would have predicted given fluctuations in cohort size (see Gruber [2001], Levitt [1999], and Shimer [2001]).

In contrast, teen drug use has continued to move with cohort size. For example, Figures I and II illustrate that the United

* I am extremely grateful to Claudia Goldin and Lawrence Katz. I am also indebted to the editor, Edward Glaeser, and three anonymous referees as well as Jennifer Amadeo-Holl, John Bound, David Cutler, Nora Gordon, Michael Grossman, Caroline Hoxby, Steven Levitt, Jeffrey Miron, Sendhil Mullainathan, Karen Norberg, Gary Solon, and participants of Harvard's labor seminar, and SAMHSA's lunchtime seminar series. Christoper Foote generously provided state-level birthrates, which he obtained from Robert Shimer, Jessica Reyes shared many state-level covariates, and Karen Norberg helped me access the restricted portions of the National Longitudinal Survey of Adolescent Health. Financial support was provided by the Social Science Research Council and The Lindesmith Center.

๑ 2004 by the President and Fellows of Harvard College and the Massachusetts Institute of Technology.

The Quarterly Journal of Economics, November 2004 


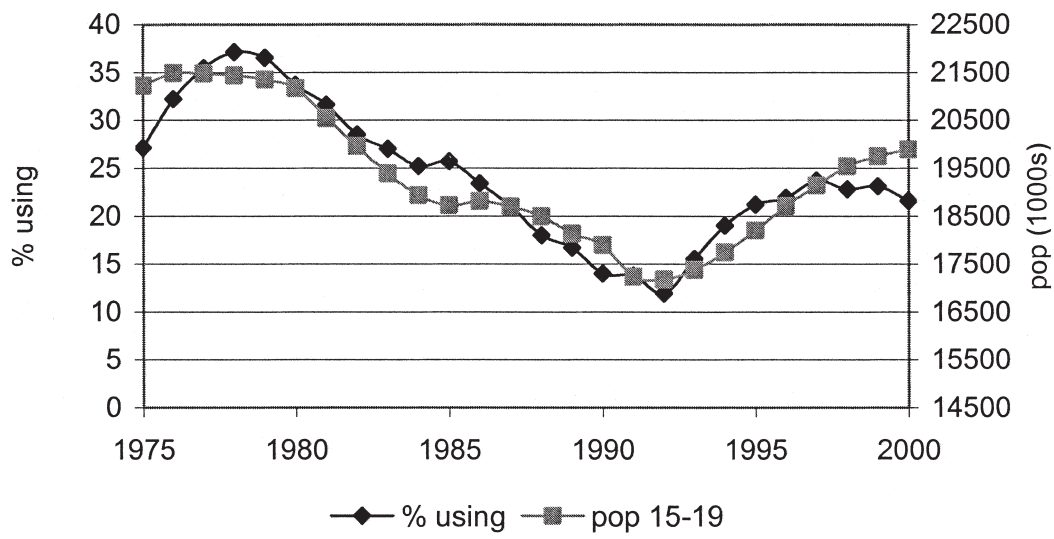

FIGURE I

Past Month Marijuana Use among High School Seniors and Cohort Size, Monitoring the Future Data 1975-2000

States national rate of past month or year teen marijuana use, between 1975 and 2000, closely tracks the population of 15 to 19 year olds. These trends in youth drug use are not well explained by the direct compositional effects of changes in youth demographic characteristics such as age, sex, and race. ${ }^{1}$ Furthermore, the relationship between youth drug use and cohort size is not driven solely by national trends. Cohort size within a census division matters for rates of youth drug use even after controlling for aggregate time effects. Across census block groups, areas of approximately 1,110 residents in 1990 , youth cohort size is also an important predictor of a teen's past month marijuana use. These findings contrast with the empirical work on violent crime [Levitt 1999; Steffensmeier et al. 1987], which shows that age and period effects dominate cohort size effects, but are consistent with property crime trends, which are (weakly) positively associated with cohort size [Levitt 1999; O'Brien 1987].

Why does the rate of youth marijuana use correlate so well with youth cohort size? I consider several hypotheses, all tied to different extents to the notion of agglomeration economiesstrained monitoring resources, scale economies in drug markets, and intergenerational attitude transfers. "Strained resources"

1. Similarly, Levitt [1999] finds that the direct compositional effects of changes in age structure do not go far in explaining overall trends in crime rates in the United States. 


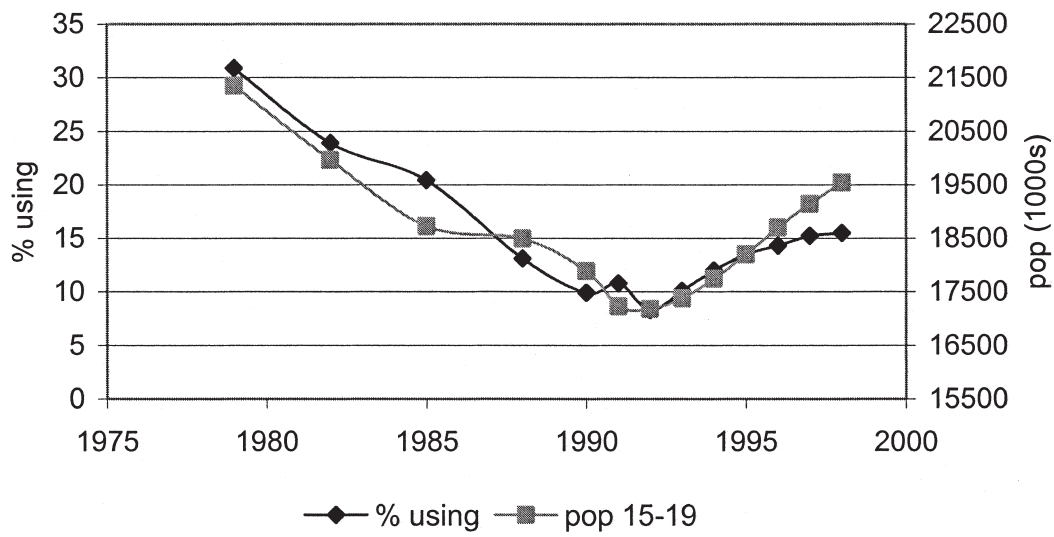

FIGURE II

Past Month Marijuana Use among 15 to 19 Year Olds and Cohort Size, National Household Survey on Drug Abuse Data 1979-1998

proposes that efforts to prevent youth drug use are overwhelmed when cohorts are large, reducing the risk of punishment and increasing use. "Scale economies" suggests that due to the fixed costs of illicit drug distribution, increases in cohort size lower the per-unit costs of drugs, reducing prices and increasing use. The final explanation considered here, "attitude transfers," suggests that the link between cohort size and drug use reflects the baby boomers' bequeathing to their kids, the baby boomlet, a relative acceptance of illicit drug use. These hypotheses are discussed in greater detail after reviewing trends in youth drug use.

I present a collage of evidence consistent with an important role for scale economies. Rates of drug sales arrests for all agegroups decline when youth cohorts are large, lowering the expected costs of drug dealing. Rates of possession arrests fall for youth alone, raising the net benefits of drug use for teens. Importantly, however, the size of the youth cohort is either unrelated or positively related to arrest rates for other "youth crimes," such as vandalism or larceny. And the price of commercial-grade marijuana, the variety typically smoked by casual users, is lower when youth cohorts are large. Finally, although a parent's attitudes help predict her teenager's marijuana use, attitude transfers account for little of the relationship between cohort size and drug use over time.

These results suggest the relative importance of efficiency gains in the illicit drug trade over a general strain on police 
resources in explaining the relationship between cohort size and drug use. An increase in youth cohort size produces a thicker youth drug market, which, through a decline in the risk of engaging in the drug trade, informational economies, and so on, generates cost-savings in distribution. Cohort size also affects youth demand through changes in possession arrest risk but the supply effect dominates, as evidenced by the negative relationship between marijuana prices and cohort size. Although this paper focuses primarily on marijuana, cohort size also matters for teen cigarette use (at the national and region level), and alcohol use (at the region and division levels), though the estimated impacts are much smaller. The explanations studied here are consistent with a cohort size effect for teen smoking and drinking, in part because they are illegal for most of this age group over most of the sample.

Section II establishes the basic relationship between youth drug use and cohort size. Section III presents a simple decomposition showing how cohort size might affect drug use. Section IV distinguishes among the proposed explanations, and Section V concludes.

\section{Trends in Drug Use and Cohort Size}

Nationally representative drug use data do not exist prior to the 1970s. Retrospective studies, however, suggest that the World War II birth cohort marks a major turning point in illicit drug use [Johnson et al. 1996]. Less than 7 percent of those born before 1940 report ever using marijuana by age 35 . In contrast, roughly 12 percent of high school seniors report using marijuana in the past month in 1992, at the trough of youth marijuana use over the past 25 years. By all indications, marijuana use, and illicit drug use more generally, rose throughout the late 1960s and 1970s.

The first year for which representative youth drug use data are available is 1975. These data, from Monitoring the Future, (MTF), a survey of high school students that has interviewed seniors annually since its inception, are the primary source of youth drug use information in the United States [Johnston, O'Malley, and Bachman 2000]. MTF is school-based and thus leaves out two groups at high risk of drug use-high school dropouts and institutionalized (e.g., imprisoned) youth. I also use the National Household Survey on Drug Abuse (NHSDA), which has interviewed the noninstitutionalized population aged twelve 
and over since 1971. NHSDA surveys were done erratically before 1990 so they give a more limited picture of trends. ${ }^{2}$ Together MTF and NHSDA provide a consistent view of casual marijuana use among teens in the United States over the past twenty-five years.

In Figure I the MTF data show an increase in past month marijuana use among high school seniors between 1975 and 1978, at the time that drug use in general peaked in the United States. Between 1978 and 1992, use fell steadily, from a peak of over 37 percent to a nadir of roughly 12 percent, and then rebounded considerably from 1992 to 1999 to over 23 percent. The trends are nearly identical for annual or lifetime use. Figure II, which shows past month marijuana use among 15 to 19 year olds in the NHSDA, tells a similar story for the 1979 to 1998 period. Both Figures I and II also show a surprisingly strong relationship between youth marijuana use and cohort size. Rates of use follow a similar pattern to the population 15 to 19 year olds-peaking with the baby boom, falling with the baby bust, and rebounding with the kids of the baby boomers. In other words, not only is the absolute number of users larger in big cohorts but the fraction as well. ${ }^{3}$

The relationship between cohort size and drug use persists at more disaggregated levels. To see this, I use the NHSDA, which does not provide as long a series as MTF but identifies respondents at the (nine) census division levels. ${ }^{4}$ I merge estimates of the youth share of the population by division-year, based on the Current Population Surveys, with the respondent-level NHSDA data from 1979 to $1997 . .^{5}$ I use a simple linear probability model, regressing an indicator of past month or year marijuana use, $d_{i g t}$, among respondents ages 15 to 19 in year $t$ and division $g$ on the share of the population 15 to 19 years old in that division and year, $s h_{g t}$, the division-year unemployment rate, $u r_{g t}$, basic demographics, $X_{i g t}$, such as age dummies (or age and age-squared

2. The first survey was completed in 1971, but the earliest publicly available data are from 1979. Data are also available for 1982, 1985, 1988, and 1990-1999. See NHSDA [1998] for more information.

3. This relationship is also found in Canada (see Ontario Student Drug Use Survey, 1977-1999). It may hold in other countries, but none, to the author's knowledge, provides a time series of youth drug use.

4. MTF provides the longest, most consistent time-series of youth marijuana use but the public-use version allows identification only at the (four) census region levels. Marijuana estimates using the MTF data are provided in the appendix (Appendix 2, Panel B) and are discussed in the text.

5. The NHSDA is currently available through 2002 but in the 1998 data respondents were categorized into six rather than nine divisions, and since 1999 the public use data no longer have geographic identifiers. 
for adults), sex and race (five categories) and division and year fixed effects, $\alpha_{g}$ and $\delta_{t}$, respectively,

$$
\operatorname{Pr}\left(d_{i g t}=1\right)=X_{i g t} \beta+\log \left(s h_{g t}\right) \gamma+u r_{g t} \pi+\alpha_{g}+\delta_{t}+\varepsilon_{i g t}
$$

(see Appendix 1 for descriptive statistics). Year and division fixed effects enable me to separate coincidental national trends and cross-sectional heterogeneity in drug use and demographics across regions from the true effect of changes in the youth share on rates of youth drug use within a region over time. ${ }^{6}$ Unemployment rates help control for any effect of regional economic conditions on substance use. ${ }^{7}$ I use the youth share rather than the absolute population so as not to overweight large areas and express the youth share in logs for ease of interpretation of later regressions. These choices have little effect on the conclusions (see Appendix 2, Panel A). ${ }^{8}$

I also adopt an instrumental variables approach, similar to Shimer [2001], using birthrates in a division 15 to 19 years earlier to separate exogenous variation in the youth share from that due to migration. I do this because families may flock to regions with high rates of marijuana use for reasons unobserved in the data but correlated with higher rates of youth drug use. For example, areas that are growing faster than usual may devote relatively more resources to education than enforcing the marijuana laws. If so, any estimated relationship between the youth share and drug use rates would not be causal.

Table Ia shows the effect of a 1 percent increase in the youth share on the probability of past month (Panel A) or year marijuana use (Panel B) among 15 to 19 year olds. Table Ib shows the effect on alcohol use over the same period. For further comparison, the effect on past month and year marijuana and alcohol use among those 30 and older is also included. Column 1 and column 3 in each panel show the results from the OLS regressions;

6. Rates of drug use vary considerably across divisions, with the Pacific typically having the highest and the South the lowest rates of youth use (see NHSDA [1998]). Since the youth share is relatively high in Southern states, cross-sectional estimates alone would associate big youth cohorts with low rates of use.

7. As Ruhm [2000] shows, mortality (and smoking and drinking, which contribute to it) is procyclical. The coefficients on unemployment rates in these regressions, however, suggest that while economic conditions impact adult use of marijuana and alcohol, their impact on youth use is more ambiguous.

8. The linear probability model (LPM) is used for ease of interpretation; using probit or logit models leads to similar conclusions. Moreover, all estimated probabilities from the LPM lie between 0 and 1 . 
TABLE Ia

Impact of Youth Share of the Population on Probability

of Past MariJuana Use among Youth and Adults:

National Household Survey on Drug Abuse: 1979-1997

\begin{tabular}{|c|c|c|c|c|}
\hline & \multicolumn{4}{|c|}{ Panel A: Past month marijuana use } \\
\hline & \multicolumn{2}{|c|}{$\begin{array}{c}15-19 \text { year olds } \\
\text { Mean use }=12.4 \%\end{array}$} & \multicolumn{2}{|c|}{$\begin{array}{c}30 \text { years } \& \text { older } \\
\text { Mean use }=4.55 \%\end{array}$} \\
\hline & OLS & IV & OLS & IV \\
\hline \multicolumn{5}{|l|}{ ln (Share pop. } \\
\hline 15-19) & $\begin{array}{l}.390 \\
(.137)\end{array}$ & $\begin{array}{l}.334 \\
(.209)\end{array}$ & $\begin{array}{l}.086 \\
(.046)\end{array}$ & $\begin{array}{c}.070 \\
(.061)\end{array}$ \\
\hline Division UR & $\begin{array}{l}.003 \\
(.003)\end{array}$ & $\begin{array}{l}.003 \\
(.003)\end{array}$ & $\begin{array}{c}-.003 \\
(.001)\end{array}$ & $\begin{array}{r}-.003 \\
(.001)\end{array}$ \\
\hline$R^{2}$ & .039 & - & .033 & - \\
\hline Observations & 40,780 & 40,780 & 81,117 & 81,117 \\
\hline
\end{tabular}

Panel B: Past year marijuana use

\begin{tabular}{|c|c|c|c|}
\hline \multicolumn{2}{|c|}{$\begin{array}{c}15-19 \text { year olds } \\
\text { Mean use }=22.1 \%\end{array}$} & \multicolumn{2}{|c|}{$\begin{array}{c}30 \text { years \& older } \\
\text { Mean use }=8.10 \%\end{array}$} \\
\hline OLS & IV & OLS & IV \\
\hline .436 & .346 & .090 & .068 \\
\hline (.164) & $(.270)$ & $(.080)$ & $(.097)$ \\
\hline .001 & .001 & -.004 & -.004 \\
\hline$(.006)$ & $(.006)$ & $(.002)$ & $(.002)$ \\
\hline .048 & - & .050 & - \\
\hline 40,780 & 40,780 & 81,117 & 81,117 \\
\hline
\end{tabular}

Standard errors in parentheses are clustered at the division (9) level to allow for correlation over time.

Coefficients represent the effect of a 1 percent change in the youth share of the population on marijuana, participation in the specified interval. The birthrate (or sum of the number of births per person) in division $d 15$ to 19 years earlier is used to instrument for the share of the population 15-19 years old.

Estimates are based on pooled NHSDA data from 1979-1997. The youth share of the population is measured at the division-year level. All regressions include controls for the respondent's sex, and race as well as division and year fixed effects and division-year unemployment rates. Regressions for 15-19 year olds include age dummies, whereas regressions for those 30 years and older control for the respondent's age and age-squared.

column 2 and column 4 show the effect of cohort size on drug use when instrumenting for the youth share with lagged birthrates. All standard errors are clustered at the division level to account for division level serial correlation [Bertrand, Duflo, and Mullainathan 2004].

In the case of youth, the relationship between marijuana use and the division-year youth share of the population is positive 
TABLE Ib

Impact of Youth Share of the Population on Probability

of Past Alcohol Use among Youth and Adults:

National Household Survey on Drug Abuse: 1979-1997

\begin{tabular}{|c|c|c|c|c|}
\hline & \multicolumn{4}{|c|}{ Panel A: Past month alcohol use } \\
\hline & \multicolumn{2}{|c|}{$\begin{array}{c}15-19 \text { year olds } \\
\text { Mean use }=36.2 \%\end{array}$} & \multicolumn{2}{|c|}{$\begin{array}{c}30 \text { years } \& \text { older } \\
\text { Mean use }=53.0 \%\end{array}$} \\
\hline & OLS & IV & OLS & IV \\
\hline \multicolumn{5}{|l|}{ ln (Share pop. } \\
\hline $15-19)$ & $\begin{array}{c}.290 \\
(.216)\end{array}$ & $\begin{array}{l}.193 \\
(.246)\end{array}$ & $\begin{array}{c}.390 \\
(.186)\end{array}$ & $\begin{array}{c}.168 \\
(.278)\end{array}$ \\
\hline Division UR & $\begin{array}{r}-.005 \\
(.006)\end{array}$ & $\begin{array}{l}-.006 \\
(.006)\end{array}$ & $\begin{array}{l}-.009 \\
(.008)\end{array}$ & $\begin{array}{r}-.011 \\
(.009)\end{array}$ \\
\hline$R^{2}$ & .077 & - & .080 & - \\
\hline Observations & 40,780 & 40,780 & 81,117 & 81,117 \\
\hline
\end{tabular}

Panel B: Past year alcohol use

\begin{tabular}{|c|c|c|c|c|}
\hline & \multicolumn{2}{|c|}{$\begin{array}{c}15-19 \text { year olds } \\
\text { Mean use }=57.0 \%\end{array}$} & \multicolumn{2}{|c|}{$\begin{array}{c}30 \text { years } \& \text { older } \\
\text { Mean use }=68.4 \%\end{array}$} \\
\hline & OLS & IV & OLS & IV \\
\hline \multicolumn{5}{|l|}{ ln (Share pop. } \\
\hline $15-19)$ & $\begin{array}{l}.304 \\
(.129)\end{array}$ & $\begin{array}{l}.310 \\
(.160)\end{array}$ & $\begin{array}{l}.309 \\
(.168)\end{array}$ & $\begin{array}{l}.106 \\
(.255)\end{array}$ \\
\hline Division UR & $\begin{array}{c}-.005 \\
(.005)\end{array}$ & $\begin{array}{c}-.003 \\
(.005)\end{array}$ & $\begin{array}{c}-.005 \\
(.009)\end{array}$ & $\begin{array}{c}-.007 \\
(.009)\end{array}$ \\
\hline$R^{2}$ & .081 & - & .050 & - \\
\hline Observations & 40,780 & 40,780 & 81,117 & 81,117 \\
\hline
\end{tabular}

Standard errors in parentheses are clustered at the division (9) level to allow for correlation over time.

Coefficients represent the effect of a 1 percent change in the youth share of the population on marijuana, participation in the specified interval. The birthrate (or sum of the number of births per person) in division $d 15$ to 19 years earlier is used to instrument for the share of the population 15-19 years old.

Estimates are based on pooled NHSDA data from 1979-1997. The youth share of the population is measured at the division-year level. All regressions include controls for the respondent's sex, and race as well as division and year fixed effects and division-year unemployment rates. Regressions for 15-19 year olds include age dummies, whereas regressions for those 30 years and older control for the respondent's age and age-squared.

and highly significant even after taking out aggregate year effects, controlling for fixed differences across geographic divisions, and controlling for the respondent's basic demographic characteristics. In contrast, the impact of the youth share of the population on adult drug use is imprecisely estimated, and although positive, the coefficients imply considerably smaller effects. Interestingly, the youth share is also positively and significantly 
related to past month and year alcohol use for youth, though, across specifications, this is not true for adults.

The results from Table Ia imply that a 10 percent increase in the youth share within a division leads to a 4 percentage point increase in the probability of past month marijuana use. Similarly, a 10 percent increase in the youth share leads to a 4.4 percentage point increase in the probability of past year marijuana use. While the precision of the IV estimates is lower, the effect of youth share on marijuana use is similar in magnitude to the OLS results and significant at the 15 and 25 percent levels for past month and year use, respectively. The implied elasticities for past month and year youth marijuana use are 2.7 and 1.6. IV results using MTF data (see Appendix 2, Panel B), which offer a longer series but have only (four) region identifiers, yield similar elasticities, 2.3 and 1.7 for past month and year marijuana use among high school seniors, and are significant below the 5 percent level. If underreporting of drug use varies with social acceptability, however, fluctuations in marijuana use rates will be exaggerated. Thus, these estimates should be treated as an upper bound on the youth cohort size effect.

For past month and year adult marijuana use, the coefficients on the youth share imply insignificant elasticities of about 2 and 1 at each sample mean. The IV approach further diminishes the precision and the magnitude of the estimates. In contrast, the youth share has a relatively stable effect on youth alcohol use across models, implying elasticities of 0.5 for both past month and year use, at the sample means. Thus, the effect of cohort size appears to be particular to youth in contrast to adults. ${ }^{9}$ Although any implications of these results are speculative, the results themselves are clear. National trends alone cannot account for the observed relationship between drug use and cohort size.

To probe the relationship further, I use restricted data from the National Longitudinal Survey of Adolescent Health (Add Health), a nationally representative survey of seventh

9. Supplementing the basic regressions with the share 5 to 14,20 to 24 , or 65 and older, has little effect on the relationship between youth cohort size and marijuana use. That the share of 20 to 24 year olds, another high crime demographic, has no or even a negative effect on youth and their own marijuana use suggests that overburdened police may not be the key to the cohort size effect. 
through twelfth graders from 134 schools in 80 communities. $^{10}$ Add Health questions respondents about a broad array of risky behaviors and links these data to the 1990 Census of Population and Housing. It provides rich data on a respondent's school and community, the respondent, and her family, which helps control for heterogeneity across areas. But because these data are nonexperimental and cross-sectional, the Add Health results are meant to be suggestive and not to imply causal relationships. ${ }^{11}$

I run a linear probability model of any lifetime or past month marijuana use on a respondent's demographics (including information about her parents' demographics and attitudes toward drug use), $X_{i}$, the log of the respondent's school size, $S C_{i}$, the $\log$ share of 15 to 19 year olds in the respondent's census block group, $s h_{i b}$, and census tract, $s h_{i T}$, where $i$ indexes individuals, $b$ block groups, and $T$ tracts (see Appendix 3 for means). ${ }^{12}$ For lifetime or past month marijuana use, the regression run is as follows:

$$
\operatorname{Pr}\left(d_{i b_{T}}=1\right)=X_{i} \beta+S C H_{i} \lambda+\log \left(s h_{i b}\right) \gamma+\log \left(s h_{i_{T}}\right) \eta+\varepsilon_{i b_{T}} .
$$

Standard errors are cluster-adjusted at the census tract level.

Table II presents results for marijuana and inhalant use (glues and solvents). Inhalants are of particular interest because, unlike marijuana, they can be bought legally by minors and are often found in the home. School size is related positively to teen marijuana but not inhalant use. A 10 percent increase in size is associated with a 0.3 percentage point in-

10. For a thorough discussion of Add Health, and many examples of its possible uses, see Jessor [1998].

11. The survey is really longitudinal, but the attrition rate of 25 percent between waves seriously weakens any results. Moreover, since the waves are only a few years apart, the contextual variables from the census are not updated. Consequently, the present analysis uses information from the first wave of the survey only.

12. The demographics used are age, age-squared, sex, race (five categories), a Hispanic indicator, foreign born, grade in school, number of siblings and its square, employment in the past month, the importance of religion, and indicators for the respondent's twin status, male-male, and female-female twin status are also included because of evidence of protective effects of the first factor and partial counteracting effects of the last two. I also control for parental education, income, unemployment status, and food stamp recipiency; and locational attributes such as the median age in the census tract, the tract unemployment rate, the county nonmarital fertility rate and nonmarital birthrate for 15 to 19 year olds, log of total serious crimes per 100,000 in the county, log of total serious juvenile crimes per 100,000 , log of per capita spending on police by local government, and the proportion of local spending going to police. 
TABLE II

Impact of School Size, Family Structure, and Parental Attitudes on Teen Substance Use: National Longitudinal Survey of Adolescent Health

\begin{tabular}{|c|c|c|c|c|}
\hline & \multicolumn{2}{|c|}{ Marijuana use } & \multicolumn{2}{|c|}{ Inhalant use } \\
\hline & Ever & Past month & Ever & Past month \\
\hline ln (Share 15-19, tract) & $\begin{array}{c}-.008 \\
(.004)\end{array}$ & $\begin{array}{c}-.007 \\
(.003)\end{array}$ & $\begin{array}{c}-.002 \\
(.001)\end{array}$ & $\begin{array}{c}-.001 \\
(.000)\end{array}$ \\
\hline ln (Share 15-19, block grp) & $\begin{array}{c}.046 \\
(.026)\end{array}$ & $\begin{array}{c}.049 \\
(.020)\end{array}$ & $\begin{array}{r}-.001 \\
(.004)\end{array}$ & $\begin{array}{l}.001 \\
(.002)\end{array}$ \\
\hline ln (School size) & $\begin{array}{l}.031 \\
(.015)\end{array}$ & $\begin{array}{l}.016 \\
(.010)\end{array}$ & $\begin{array}{c}-.002 \\
(.004)\end{array}$ & $\begin{array}{c}-.001 \\
(.001)\end{array}$ \\
\hline $\begin{array}{l}\text { Parent lives in } \\
\text { neighborhood for lower } \\
\text { teen drug use }\end{array}$ & $\begin{array}{r}-.102 \\
(.033)\end{array}$ & $\begin{array}{c}-.029 \\
(.028)\end{array}$ & $\begin{array}{r}-.001 \\
(.006)\end{array}$ & $\begin{array}{r}-.003 \\
(.003)\end{array}$ \\
\hline Parent drinks heavily & $\begin{array}{l}.100 \\
(.045)\end{array}$ & $\begin{array}{c}.049 \\
(.039)\end{array}$ & $\begin{array}{l}.042 \\
(.031)\end{array}$ & $\begin{array}{c}.007 \\
(.018)\end{array}$ \\
\hline Parent smokes cigarettes & $\begin{array}{c}.074 \\
(.035)\end{array}$ & $\begin{array}{c}.105 \\
(.035)\end{array}$ & $\begin{array}{c}.011 \\
(.005)\end{array}$ & $\begin{array}{l}.008 \\
(.003)\end{array}$ \\
\hline Number of siblings & $\begin{array}{r}-.041 \\
(.013)\end{array}$ & $\begin{array}{r}-.028 \\
(.014)\end{array}$ & $\begin{array}{r}-.005 \\
(.003)\end{array}$ & $\begin{array}{l}.002 \\
(.001)\end{array}$ \\
\hline $\begin{array}{l}\text { Missing parent survey } \\
\text { dummy }\end{array}$ & $\begin{array}{l}.029 \\
(.060)\end{array}$ & $\begin{array}{l}.071 \\
(.054)\end{array}$ & $\begin{array}{r}-.010 \\
(.007)\end{array}$ & $\begin{array}{r}-.004 \\
(.003)\end{array}$ \\
\hline Missing census information & $\begin{array}{r}-.028 \\
(.036)\end{array}$ & $\begin{array}{r}-.080 \\
(.040)\end{array}$ & $\begin{array}{r}-.029 \\
(.013)\end{array}$ & $\begin{array}{r}-.014 \\
(.004)\end{array}$ \\
\hline Mean use & $28.6 \%$ & $14.4 \%$ & $6.04 \%$ & 1.56 \\
\hline Observations & 17,147 & 16,936 & 16,836 & 16,836 \\
\hline$R^{2}$ & .147 & .136 & .023 & .010 \\
\hline
\end{tabular}

Standard errors are cluster-adjusted by census tract and are shown in parentheses.

See Appendices 3 and 4 for descriptive statistics and precise variable definitions.

Regressions control for age, age-squared, sex, race (5), whether Hispanic, whether native born, grade in school, the employment status of the adolescent respondent in the last month, the importance of religion to the respondent, size of the school the respondent attends, number of siblings in household and its square. Controls from parental (90 percent maternal) surveys include parent's education, log of family income, unemployment status, smoker status, food stamp recipiency status, parent's assessment of problems with drug-dealing, and drug use in their neighborhood, whether they live in the neighborhood because of low crime or low levels of teen drug use. All regressions also control for the median age in the census tract, the tract-level unemployment rate, the county nonmarital fertility rate, the county nonmarital birthrate for 15 to 19 year olds, log of total serious crimes per 100,000 in the county, log of total serious juvenile crimes per $100,000, \log$ of per capita spending on police by local government, and the proportion of local spending going to police.

crease in the probability of lifetime marijuana use, implying an elasticity of about 0.1 evaluated at the sample means of the data. This result suggests that congestion at the school level, allowing drug dealers and buyers in the area to act with 
relative impunity, may help explain the relationship between drug use and cohort size. ${ }^{13}$

The youth share in a block group is also positively related to marijuana use, although it has no consistent effect on inhalant use. A 10 percent increase in the share of 15 to 19 year olds in a block group raises the probability of both lifetime and past month use by almost 0.5 percentage points, implying elasticities of about 0.2 and 0.3 . In contrast, the share in a census tract, an area of four to five block groups, has a small but significant negative effect on marijuana use, implying elasticities of -0.03 for past month and -0.05 for lifetime. The distinction between the group and tract results coupled with the school size findings suggests that a teen's decision to use marijuana may be more directly affected by youth in the immediate vicinity. Together with the census division results, this suggestive evidence on school size and block groups reinforces the possibility of a substantive relationship between youth drug use and cohort size.

\section{A Framework for Understanding the Cohort Size Effect}

Below I present a simple decomposition, following Glaeser and Sacerdote [1999], to provide a framework for understanding how youth cohort size might affect drug use at the extensive margin. Unlike these authors, who consider criminality across space, this decomposition conceptualizes the role of changes in youth cohort size across time on the level of youth drug use within a given location.

Teens use illicit drugs when the benefits $(B)$ exceed the $\operatorname{costs}(\theta+P C)$. I divide costs into those $(\theta)$ associated with drug use itself (such as purchase price, social opprobrium, a potential bad reaction, and so on) and those related to the expected external costs of use, the probability of arrest $(P)$ times the cost of punishment $(C)$. The cost $(\theta)$ associated with youth drug use itself is a function of a vector $\mathbf{X}$ of individual characteristics, which are correlated with and determined by cohort size $(S)$. The benefits of drug use to a teen and the probability of arrest

13. Sibling size also warrants discussion. Having more siblings lowers the probability of drug use. This may reflect the type of families with more kids (e.g., religious or poor) or may protect against boredom, a prime motive for youth drug use [Glassner and Loughlin 1987]. Alternatively, larger families may have fewer resources per child and their kids less spending money for drugs. 
are both direct functions of cohort size $(S)$. In addition, the benefits $(B)$ are an increasing function of the total number of drug users, $(Q)$. The cost of punishment $(C)$ is assumed, however, to be constant across cohorts of varying size as well as numbers of drug users within a given location. For further simplicity, I assume that all potential teen drug users in a given youth cohort and location have the same $\mathbf{X}$ variables. The youth drug use equilibrium is given by

$$
B(S, Q)=\theta(\mathbf{X})+P(S) C .
$$

Differentiating (3) with respect to cohort size $(S)$ to determine the ways in which youth cohort size affects the level of youth drug use:

$$
\frac{\partial Q}{\partial S}=\frac{C}{B_{Q}} P^{\prime}(S)-\frac{B_{S}}{B_{Q}}+\frac{d X}{d S} \frac{\theta_{X}}{B_{Q}} .
$$

Expressing this in terms of elasticities,

$$
\varepsilon_{S}^{Q}=\varepsilon_{P}^{Q} \varepsilon_{S}^{P}-\frac{B}{P C} \varepsilon_{P}^{Q} \varepsilon_{S}^{B}+\sum_{x} \varepsilon_{S}^{x} \varepsilon_{x}^{Q},
$$

where $\varepsilon_{P}^{Q}=(P / Q)(\partial Q / \partial P)=P C / Q B_{Q}$. In words, cohort size may affect rates of youth drug use by altering (1) the probability of arrest $\left(\varepsilon_{P}^{Q} \varepsilon_{S}^{P}\right)$ or (2) the returns from use $\left[(B / P C) \varepsilon_{P}^{Q} \varepsilon_{S}^{B}\right]$ or (3) individual apprehension-invariant costs of crime $\left(\varepsilon_{S}^{x} \varepsilon_{x}^{Q}\right)$.

How might cohort size affect the probability of arrest? Larger cohorts may strain society's resources for monitoring. As school resources are spread thin when cohorts are large [Bound and Turner 2004; Poterba 1997], crowding may make it difficult for teachers to monitor students. Police may be less able to patrol neighborhoods and clamp down on drug trafficking to and among youth. And, the relatively fixed slots for incarceration may necessitate police turning a blind eye to the drug trade. By lowering the probability of getting caught, such congestion would affect users, by raising the net benefits of consumption, or dealers, by lowering total supply costs.

How might cohort size affect the returns? Larger cohorts may generate economies in drug distribution. Dealers need to make connections with clients, establish safe pickup and dropoff locations, and maintain viable financing schemes. The penalty structure for, and thus expected cost of, drug trafficking is also nonlinear with respect to quantity, even flattening out 
above a certain threshold. ${ }^{14}$ The existence of such fixed costs may generate price fluctuations in response to idiosyncratic changes in cohort size. Assuming a given fraction of youth users, a larger cohort means a larger number of youth users. Yet, the increase in output required to meet the increased demand should require a less than proportionate increase in resources to evade the authorities, deliver drugs, and so on. For example, a thicker market might provide a better network of information on where to "safely" buy and sell illicit drugs. The reduction in the unit cost of distributing illicit drugs translates into lower prices, which feeds back to youth use.

How might larger youth cohorts "affect" individual preferences for drug use? Social interactions and peer effects may be more important in larger cohorts. Exposure to a drug-using peer, which increases in likelihood when cohorts are large, may have a multiplicative effect on teen drug use. In addition, the relative size of a cohort may itself impact culture and thus the acceptance of youth drug use. More specific to the U. S. context, the baby boomers, the cohort with the highest known rates of drug use in U. S. history, may have passed on to their kids, the baby boomlet, a relative acceptance of illicit drug use. Indeed, it is the children of the baby boomers, those who reached adolescence in the $1990 \mathrm{~s}$, who are responsible for rising rates of drug use in the $1990 \mathrm{~s}$, after a decade of declines. Thus, the increase in rates of youth drug use may not be substantively related to the increase in cohort size but rather reflect parental attitudes toward drug use.

The work below attempts to parameterize this decomposition, combining new estimates of the effects of youth cohort size on drug arrest rates and prices with existing estimates of arrest elasticities. Ultimately, this exercise will help determine what share of the relationship between youth drug use and cohort size is due to the effect of cohort size on (1) drug arrest probabilities, (2) marijuana prices, or (3) individual preferences.

14. The economies discussed are in some cases internal (e.g., the nonlinear penalty structure) and others external (e.g., search costs for recruiting dealers). Each has different implications for the drug market since economies of scale at the firm level are inconsistent with perfect competition at the industry level. 


\section{Testing Alternative Explanations}

\section{IV.A. Drug Arrests Rates and the Role of Strained Police Resources, $\varepsilon_{P}^{Q} \varepsilon_{S}^{P}$}

Drug offense rates should parallel use rates. If police can keep up with these trends, youth marijuana arrest rates, particularly for possession, should follow use rates and cohort size. If law enforcement resources are strained, however, arrests could increase less than proportionately or even decrease if a more efficient illicit drug market emerges.

To assess these possibilities, I use data from the Uniform Crime Reporting (UCR) program's "Arrest Reports by Age, Sex and Race for Police Agencies in Metropolitan Statistical Areas." I look at sales and possession offenses separately to get a sense of differential impacts on the supply and demand sides of the market. $^{15}$ Table III gives means of marijuana and all drug arrests rates (sale or possession among the specified group as a fraction of those in the group) aggregated up to the state-year level for 1976-1997. ${ }^{16}$ Arrest "risk" for marijuana possession or sales is 8 to 12 times greater for 15 to 19 year olds than for those 30 years and older. In addition, and in contrast to adults, youth drug arrests occur disproportionately in the marijuana trade.

Table IV looks at the effect of changes in the youth share on marijuana sales and possession arrest rates of youth and adults separately as well as for the entire population (Panel A). For comparison, I also consider arrest rates for all illicit drug sales and possession offenses (Panel B) as well as larceny and vandalism (Panel $\mathrm{C}$ ), two arrest categories that, according to Table III, are also dominated by 15 to 19 year olds. ${ }^{17}$

The setup is similar to (1) except the dependent variable in Panel A is at the state-year level. I run a regression of the log of the arrest rate in state $s$ at time $t, a_{s t}$, by age group (youth, adults, and all ages) and offense (sales or possession) on the log of

15. The distinction between sales and possession may be somewhat artificial since it is based on the amount of a substance found on an offender. Those charged with drug sales offenses, however, are almost certainly involved in distribution at a high level. Thus, the evidence on sales arrest rates provides the clearest picture of what is happening on the supply-side of the drug market.

16. UCR data have been collected since 1960 , but reporting was spotty until 1976, when local police were required to submit data. See Schneider and Wiersema [1990] for a discussion of the limits of UCR data.

17. Due to significant missing observations, data from Alaska, Delaware, Florida, Hawaii, Illinois, Kansas, Montana, New Hampshire, South Dakota, Vermont, and Wyoming are not included here. 
Drug Sales and Possession Arrest Rates: 1976-1997, Descriptive Statistics

\begin{tabular}{lccc}
\hline \hline & $\begin{array}{c}\text { Full } \\
\text { sample }\end{array}$ & $\begin{array}{c}\text { 15-19 year } \\
\text { olds }\end{array}$ & $\begin{array}{c}\text { 30 years } \\
\text { \& older }\end{array}$ \\
\hline Youth share & .082 & - & - \\
Marijuana sales arrests per 100,000 & $(.011)$ & & \\
& 15.2 & 51.5 & 6.41 \\
All drug sales arrests per 100,000 & $(13.4)$ & $(61.0)$ & $(5.79)$ \\
Marijuana possession arrests per 100,000 & 51.1 & 149 & 28.7 \\
& $(13.4)$ & $(229)$ & $(35.6)$ \\
All drug possession arrests per 100,000 & 51.1 & 339 & 27.5 \\
& $(61.0)$ & $(284)$ & $(21.4)$ \\
Larceny arrests per 100,000 & 81.2 & 463 & 71.4 \\
& $(55.6)$ & $(388)$ & $(80.1)$ \\
Vandalism arrests per 100,000 & 366 & 1373 & 184 \\
Population (100,000s) & $(205)$ & $(775)$ & $(119)$ \\
& 68.2 & 286 & 21.9 \\
Observations & $(15.9)$ & $(215)$ & $(16.6)$ \\
& 53.8 & 4.30 & 28.6 \\
\hline \hline
\end{tabular}

Mean is given in each cell. Standard deviation appears in parentheses. Youth share of the population and arrest rates are measured at the state-year level for 1976-1997. Arrest data are generated from MSA-level Uniform Crime Reports. Due to significant missing observations, the following states are excluded: AK, DE, FL, HI, IL, KS, MT, NH, SD, VT, and WY. Arrest rates are given per 100,000 of the target population, i.e., 15-19 year olds, 30 years and older, or total population.

the share of the population 15 to 19 years old in a state and year, $s h_{s t}$, instrumented by 15 to 19 year lagged birthrates, the annual state unemployment rate $u r_{s t}$, to capture economic conditions, state fixed effects $\alpha_{s}$, division-year fixed effects $\delta_{g(s), t}$, to pick up regional fluctuations in arrest rates, and an error $\varepsilon_{s t}$ term to capture variation in drug arrest rates that is orthogonal to the youth share:

(6) $\log \left(a_{s t}\right.$, by age group and offense)

$$
=\log \left(s h_{s t}\right) \gamma+u r_{s t} \pi+X_{s t} \beta+\alpha_{S}+\delta_{g(s), t}+\varepsilon_{s t} .
$$

These regressions also include a set of state characteristics $X_{s t}$ : the log of prisoners per capita and police per capita to capture law enforcement intensity (both lagged one year to minimize endogeneity between crime rates and enforcement), the log of state income per capita (in 1997 dollars) as an additional measure of state economic conditions, and a dummy for the presence of a 
TABLE IV

Estimates OF THE IMPACT OF Youth SHARE ON MARIJUANA

AND OTHER ARRest RATES: 1976-1997

Panel A: State-year level marijuana arrest rates

\begin{tabular}{cccccc}
\hline \multicolumn{3}{c}{ Marijuana sales } & \multicolumn{3}{c}{ Marijuana possession } \\
\cline { 1 - 3 } \cline { 5 - 6 } $\begin{array}{c}15-19 \text { year } \\
\text { olds }\end{array}$ & $\begin{array}{c}30 \text { years \& } \\
\text { older }\end{array}$ & All ages & $\begin{array}{c}\text { 15 year } \\
\text { olds }\end{array}$ & $\begin{array}{c}\text { years \& } \\
\text { older }\end{array}$ & All ages \\
-4.44 & -3.10 & -3.87 & -1.67 & 1.69 & .023 \\
$(1.00)$ & $(1.09)$ & $(1.12)$ & $(1.33)$ & $(1.66)$ & $(1.28)$ \\
854 & 848 & 854 & 854 & 853 & 854 \\
\hline
\end{tabular}

Panel B: State-year level all drug arrest rates

\begin{tabular}{|c|c|c|c|c|c|c|}
\hline & \multicolumn{3}{|c|}{ Drug sales } & \multicolumn{3}{|c|}{ Drug possession } \\
\hline & $\begin{array}{c}\text { 15-19 year } \\
\text { olds }\end{array}$ & $\begin{array}{l}30 \text { years \& } \\
\text { older }\end{array}$ & All ages & $\begin{array}{c}15-19 \text { year } \\
\text { olds }\end{array}$ & $\begin{array}{l}30 \text { years \& } \\
\text { older }\end{array}$ & All ages \\
\hline \multicolumn{7}{|l|}{ ln (Share pop. } \\
\hline $15-19)$ & $\begin{array}{c}-6.70 \\
(1.75)\end{array}$ & $\begin{array}{c}-2.95 \\
(1.05)\end{array}$ & $\begin{array}{c}-4.33 \\
(1.39)\end{array}$ & $\begin{array}{c}-1.98 \\
(1.10)\end{array}$ & $\begin{array}{c}1.12 \\
(1.10)\end{array}$ & $\begin{array}{c}-.539 \\
(.955)\end{array}$ \\
\hline
\end{tabular}

Panel C: State-year level other arrest rate regressions

\begin{tabular}{|c|c|c|c|c|c|}
\hline \multicolumn{3}{|c|}{ Larceny } & \multicolumn{3}{|c|}{ Vandalism } \\
\hline $\begin{array}{l}\text { 15-19 year } \\
\text { olds }\end{array}$ & $\begin{array}{l}30 \text { years \& } \\
\text { older }\end{array}$ & All ages & $\begin{array}{c}\text { 15-19 year } \\
\text { olds }\end{array}$ & $\begin{array}{l}30 \text { years \& } \\
\text { older }\end{array}$ & All ages \\
\hline $\begin{array}{l}.577 \\
(.613)\end{array}$ & $\begin{array}{c}-.205 \\
(.511)\end{array}$ & $\begin{array}{l}.828 \\
(.452)\end{array}$ & $\begin{array}{c}-.824 \\
(.525)\end{array}$ & $\begin{array}{l}.843 \\
(.901)\end{array}$ & $\begin{array}{l}.288 \\
(.546)\end{array}$ \\
\hline
\end{tabular}

Standard errors are cluster-adjusted by state and are shown in parentheses. Coefficients represent the elasticity of the indicated arrest rate with respect to the share of the total population that is 15-19 years old.

Observations are at the state-year level. Data are generated from MSA-level Uniform Crime Reports. Due to significant missing observations, data from AK, DE, FL, HI, IL, KS, MT, NH, SD, VT, and WY are not used. Estimates should include 858 observations, 39 states over 22 years. Deviations are due to missing data in some state-year cells. The birthrate (or sum of the number of births per person) in state $s 15$ to 19 years earlier is used to instrument for the share of the population 15-19 years old.

All regressions include state and division-year fixed effects, annual state unemployment rates, the log of prisoners per capita lagged one year, the log of police per capita lagged one year, the log of state income per capita (in $97 \$$ ), and a dummy for the presence of a concealed handgun law.

concealed handgun law. To account for the fact that even unanticipated increases in arrest rates dissipate gradually, in part because of the artificiality of year intervals, standard errors are clustered at the division-level.

The results in Panel A are negative for all age categories of 
marijuana sales arrests and for youth possession arrest rates: an increase in the youth share of the population is associated with a decrease in youth marijuana arrest rates. For youth sales, the elasticity is -4.4 ; for total marijuana sales arrests the elasticity is almost -4 . Since a larger cohort also leads to higher rates of youth drug use, these estimates actually understate the change in youth marijuana arrest risk. The IV estimate of the youth share elasticity of past year youth marijuana use rates (1.6), suggests a 10 percent increase in the youth share translates into a roughly 7 percent reduction in youth sales arrests per drug user.

The results for total drug sales in Panel B are similar to those for marijuana. ${ }^{18}$ That all drug sales arrest rates fall in response to an increase in the youth share suggests that something is occurring on the supply-side of the market: a squeeze on police resources, a more efficiently operating drug trade, a greater acceptance of youth culture. Panel C, which shows that a larger youth cohort is associated with higher arrest rates for larceny, confirms the basic finding: something particular to illicit drug markets is driving the negative relationship between cohort size and drug sales arrest rates.

While marijuana sales arrest rates decrease across age groups, possession arrests display a different pattern. Increases in youth cohort size are associated with decreases in youth possession arrests. A 1 percent increase in cohort size is associated with an (insignificant) 1.6 percent reduction in youth marijuana possession arrest rates and a (significant) 2 percent reduction in overall youth drug possession arrest rates. In contrast, increases in youth cohort size seem to increase adult possession arrest rates. A larger youth cohort raises the net benefit of consumption for youth, through a decline in the expected costs of using illicit drugs, but lowers that for adults. The differential effect of the youth share on adult possession arrest risk may explain why, despite the decline in marijuana prices shown below, increases in youth cohort size have little effect on adult marijuana use rates.

18. The results are also similar without controls for law enforcement intensity, handgun laws, or local economic conditions, suggesting that these covariates are not driving the relationship between cohort size and marijuana arrest rates. Similarly, using year rather than division-year fixed effects has little effect on the magnitude or precision of the results, suggesting that regional fluctuations do not drive the results. Results from division-year regressions are also quite similar, although the precision of the estimates drops considerably. 
Alternatively, adults may simply be less sensitive to price changes.

The youth share effect on drug arrest rates is undiminished when the share of 20 to 24 year olds, another high-crime demographic, is added to these regressions (not shown here). This suggests that the impact of the youth share on police resources is not purely compositional. Police, perhaps exasperated by the relative number of youth in their area, do not simply shift their resources to monitor the drug involvement of other high-crime age groups. Rather, an increase in the youth share is associated with a decrease in enforcement of the drug laws or a greater ability of drug dealers to evade the authorities. An increase in 20 to 24 year olds may also overwhelm the police, but it does little to alter the relationship between the youth share and either youth or total sales arrest rates. Thus, a strain on police resources may not capture the full effect of cohort size on use rates.

Ethnographic studies of drug markets suggest another reason an increase in the youth share of a population could benefit illicit drug suppliers. In the 1970s, criminal penalties became more severe for adults or more lenient for juveniles. In consequence, teenagers were explicitly recruited for and employed in street-level drug sales [Padilla 1992]. Thus, an increase in the youth share may offer "employers" a bigger source of talented drug dealers, effectively lowering search costs and the unit costs of illicit drug dealing.

How much of the relationship between youth drug use and cohort size can be explained by changes in drug arrest probabilities? To determine this, we need an estimate of $\varepsilon_{P}^{Q}$, the elasticity of drug use with respect to the probability of arrest or other measures of deterrence. Estimates from the literature, which focus largely on monetary fines, vary considerably, from finding no statistically significant effect of higher median fines on youth possession [Farrelly et al. 1999] to small negative elasticities of -0.008 on past year youth marijuana participation [Chaloupka, Grossman, and Tauras 1999]. Estimates of deterrence elasticities for property crimes are closer to -0.2 [Levitt 1998; Glaeser and Sacerdote 1999]. Using the -0.008 elasticity as a lower bound on drug use responsiveness and my estimated -2 elasticity of youth drug possession with respect to cohort size, changes in arrest probabilities can only explain about 1 percent $(-2 *-.008 / 1.6)$ of the relationship between youth drug use and cohort size. The property crime deterrence elasticity, however, suggests that 
changes in arrest risk explain closer to 25 percent of the relationship.

\section{IV.B. Marijuana Prices and Economies of Scale, $(B / P C) \varepsilon_{P}^{Q} \varepsilon_{S}^{B}$}

Complementary to the strain on police resources is the possibility that increases in cohort size lead to thicker marijuana markets and lower the delivered price of the drug. For example, when the population of youth in an area increases, drug dealers may find it worthwhile to make the fixed investment in setting up a local supply network, effectively lowering the marginal cost of illicit drugs in the area. A testable implication is that marijuana prices fall when youth cohort size increases.

I construct marijuana prices from two different sources, each with its own drawbacks. The first, High Times, is a marijuana "fanzine" that has been published monthly since 1975. In each issue, contributors to the "Trans High Market Quotations" (THMQ) section write in with descriptions and prices of marijuana in their part of the country. For a given month and year, a typical observation lists a contributor's state, describes the marijuana available according to source country or state (Mexico, Colombia, Jamaica, California, Hawaii, etc.) and quality (commercial grade, sensimilla, etc.), and finally gives a price. Ideally one would like to deflate these prices by a measure of potency, but such information is unavailable. I take a second best approach, identifying prices that fit one of two categories: low quality or commercial grade Colombian and Mexican "weed" and high quality or Californian and Hawaiian sensimilla. For tractability, within each quality category, I follow the ten most commonly represented states: Alaska, California, Georgia, Hawaii, Michigan, Missouri, New York, Oregon, Tennessee, and Texas.

The second source is the Drug Enforcement Administration's (DEA) System to Retrieve Information from Drug Evidence (STRIDE), which records purchases and seizures of illegal drugs made by undercover DEA agents and informants as well as the Metropolitan Police of the District of Columbia from 1974 onwards. ${ }^{19}$ Recent work questions STRIDE's appropriateness for analyses of drug prices [Horowitz 2001]. For marijuana prices, STRIDE presents additional challenges. Because the DEA fo-

19. STRIDE data were first recorded in 1970, but there are few observations before 1974. A typical observation reports the drug, its weight and purity, the city where it was acquired, the date the transaction occurred, and the price paid, if it was purchased. See Frank [1987] for a thorough discussion of STRIDE. 


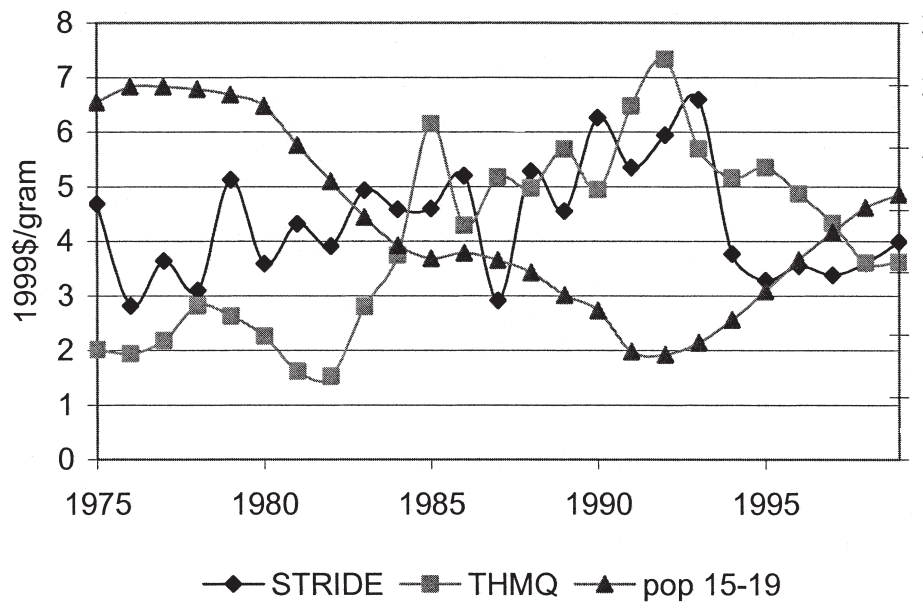

22500

21500

20500

19500

18500

17500

16500

15500

Figure III

Youth Cohort Size and Real Marijuana Prices from DEA and High Times Data, 1975-1999

cuses on harder drugs, marijuana observations are only a small fraction of all purchases (6,500 compared with 50,000 for heroin between 1974 and 2000). Moreover, over 40 percent of the marijuana data are from the District of Columbia Metropolitan Police. Texas, the most highly represented state, contributes less than 7 percent of the data. In addition, less than 10 percent of marijuana observations include purity estimates, which, given anecdotal evidence of significant increases in purity over the past 25 years [Harrison 1995], makes these price data far from ideal. ${ }^{20}$ Nonetheless, because of the general dearth of illicit drug price data, I use STRIDE for comparative purposes. $^{21}$

Figure III plots median prices per gram in 1999 dollars for the low quality marijuana in THMQ and all marijuana observations in STRIDE from 1975-1999. For comparison, it also shows the population of 15 to 19 years old in thousands. The high quality marijuana price series is omitted because it is even noisier than these two and greatly obscures the figure. Moreover, the low quality category is most relevant for the present analysis as

20. Pacula et al. [2001] uses secondary DEA sources to get marijuana prices for 1981-1998. These data are rather crude, however, with prices given in broad ranges and purity available only at the national level.

21. As Caulkins [2001] points out, we can hardly be better informed by ignoring STRIDE data. 
it is the type of marijuana most likely used by casual users. As seen in Table V, a gram of sensimilla (high quality marijuana) costs almost three times as much as a gram of commercial (low quality) marijuana.

In the aggregate, both the THMQ low quality and STRIDE price series are negatively related to the population 15 to 19 years old and thus rates of marijuana use among this age group. In other words, marijuana prices are low when the youth cohort size is large and rates of use are high. Judging from the THMQ series, the increase in marijuana prices in the 1980s followed the reduction in cohort size while the decrease in the 1990s was contemporaneous with the increase in cohort size. In contrast, STRIDE data suggest that the price increase may have began in the mid-1970s, before the decrease in cohort size, whereas the decrease in the 1990s occurred after the initial increase in cohort size. These inconsistencies may be related to the different composition of states in each series.

To better interpret the relationship among marijuana use, prices, and cohort size, I would like to supplement the basic marijuana use regressions in (1) with both prices and the expected cost of punishment to determine whether the relationship between drug use and cohort size works exclusively through

TABLE V

Descriptive Statistics for Illicit Drug Price Data

\begin{tabular}{|c|c|c|c|}
\hline & \multicolumn{3}{|c|}{ Median prices per gram (1999 Dollars) } \\
\hline & All & Retail & Wholesale \\
\hline High quality marijuana, THMQ & $\begin{array}{l}9.17 \\
{[2.25,18.25]}\end{array}$ & - & - \\
\hline Low quality marijuana, THMQ & $\begin{array}{l}3.17 \\
{[.529,10.6]}\end{array}$ & - & - \\
\hline All marijuana, STRIDE & $\begin{array}{l}3.14 \\
{[.128,29167]}\end{array}$ & - & - \\
\hline Cocaine, pure grams & $\begin{array}{l}215 \\
\quad[36.6,5982]\end{array}$ & $\begin{array}{l}180 \\
{[57,22740]}\end{array}$ & $\begin{array}{l}45.3 \\
{[.444,569]}\end{array}$ \\
\hline Heroin, pure grams & $\begin{array}{l}306 \\
{[35.4,112676]}\end{array}$ & $\begin{array}{l}1676 \\
{[209,2820513]}\end{array}$ & $\begin{array}{l}246 \\
{[.784,40000]}\end{array}$ \\
\hline
\end{tabular}

The high quality THMQ marijuana statistics are based on 250 observations, ten states over 25 years. The states included are AK, CA, GA, HI, MI, MO, NY, OR, TN, and TX. The low quality THMQ statistics are based on 200 observations, all states listed above, except AK and HI, over 25 years. The STRIDE statistics are based on 100 observations, CA, DC, FL, NY, and TX, over 25 years. 
price. ${ }^{22}$ Due to data limitations, I instead run a simple panel regression of the log of marijuana prices per gram in state $s$, and year $t$ on the log of the youth share, $s h_{s t}$, the annual state unemployment rate $u r_{s t}$, to capture state economic conditions, state and year fixed effects, $\alpha_{s}$ and $\delta_{t}$, and an error $\varepsilon_{s t}$ term:

(7) $\log \left(\right.$ price per $\left.\operatorname{gram}_{s t}\right)=\log \left(s h_{s t}\right) \gamma+u r_{s t} \pi+\alpha_{S}+\delta_{t}+\varepsilon_{s t}$.

The regression is run separately for each price series-THMQ low quality, THMQ high quality, and STRIDE from 1975 to 2000. For the STRIDE series I have a balanced panel for only five statesCalifornia, the District of Columbia, Florida, New York, and Texas. For the high quality THMQ regressions, all ten statesAlaska, California, Georgia, Hawaii, Michigan, Missouri, New York, Oregon, Tennessee, and Texas-are included. The low quality regressions omit Alaska and Hawaii because of significant numbers of missing observations. Standard errors are again clustered by state.

Table VI, Panel A shows the results from (7), instrumenting for the youth share with lagged birthrates. While both the high quality THMQ and STRIDE estimates are too imprecisely estimated to draw conclusions, the low quality THMQ prices are clearly negatively related to cohort size. In particular, they suggest an elasticity of about -2 with respect to the share of the population 15 to 19 years old. Panel B further probes the youth share effect on low and high quality marijuana prices. I also include the share of 20 to 24 year olds in the state because high quality marijuana users tend to be older. The IV results, which instrument for both the share 15 to 19 and 20 to 24 years old, continue to show a negative effect of the youth share on low quality marijuana prices.

Table VI provides the best evidence for the economies of scale hypothesis. Why should a larger youth cohort lead to lower marijuana prices, particularly given the higher rates of use associated with larger cohorts? Supply-side factors must dominate for use and prices to move in opposite directions. Thicker markets may generate cost-savings in distribution, translating into lower prices and higher rates of use. ${ }^{23}$

22. Since prices are only available for ten states and neither the NHSDA nor MTF provides state-identifiers, such analysis is currently infeasible. Restricted access to MTF state-identifiers will remedy this problem.

23. This finding is consistent with Pacula et al. [2001], which suggests that marijuana prices and potency explain much of the trend in youth marijuana use, 
TABLE VI

Estimates of the Impact of Youth Share of the Population on THMQ AND STRIDE MARIJUANA PRICES, By StATE: 1975-1999

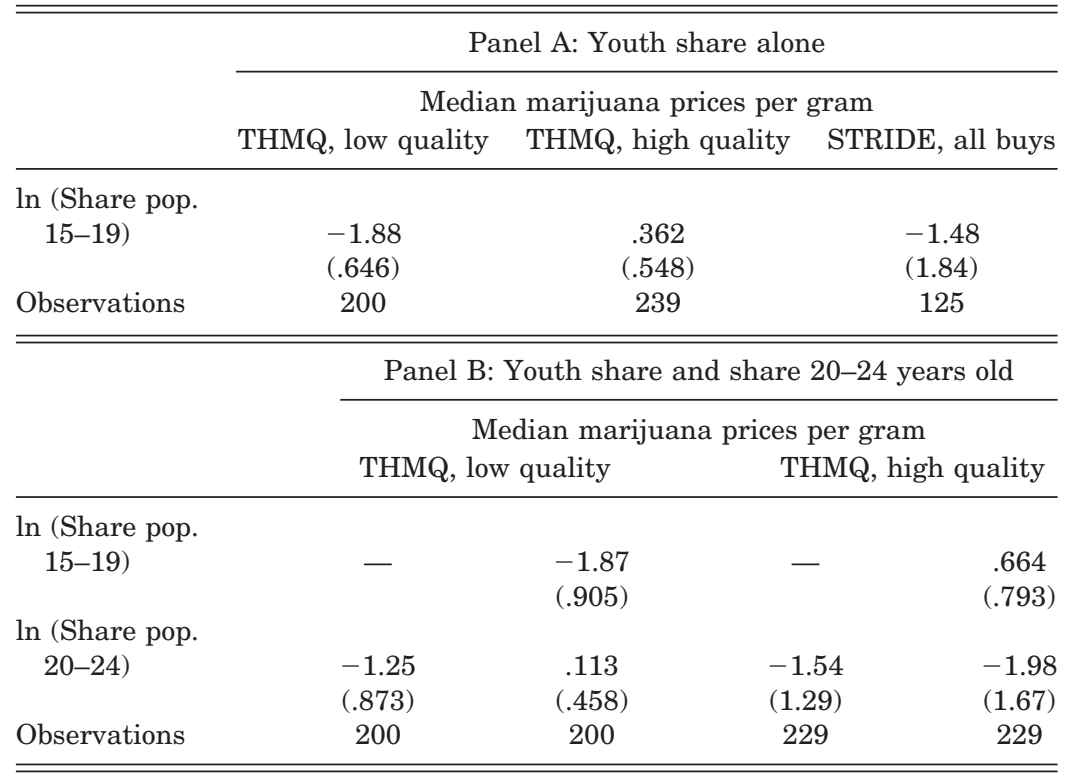

Standard errors are cluster-adjusted by state and are shown in parentheses.

Observations are at the state-year level. Price data come from High Times' monthly Trans High Market Quotations (THMQ) and the DEA's System to Retrieve Drug Information from Evidence (STRIDE). Each price observation is the median price per gram of either high or low quality marijuana in a given state and year or of all DEA buys in a given state and year. Quality is based on author-assessment and on the source country and type of marijuana listed. Low quality is generally Colombian or Mexican "commercial weed," whereas high quality is Californian sensimilla or a Hawaiian variety such as "Puna Gold."

Coefficients represent the elasticity of the indicated price per pure gram with respect to the share of the total population that is 15-19 years old. The birthrate (or sum of the number of births per person) in state $s 15$ to 19 years earlier is used to instrument for the share of the population 15-19 years old. All regressions include year and state fixed effects. States included in the THMQ high quality price regressions are AK, CA, GA, HI, MI, MO, NY, OR, TN, and TX. AK and HI are omitted from the low quality price regressions because over half of the observations for each state are missing. States included in the STRIDE regressions are CA, DC, FL, NY, and TX.

To assess the effect of cohort size on the returns to drug use, we need an estimate of the ratio $B / P C$, the benefits of drug use over law-related expected costs. As a minimum measure of benefits, I use the average monetary cost of a half an ounce of commercial grade marijuana over the sample period, $\$ 42$ (14 grams * $\$ 3 /$ gram). The youth marijuana possession arrest rate in Table

but goes a step further by establishing a mechanism behind the trends in both prices and use rates. 
III, 339 per 100,000 residents, and the average rate of past year youth marijuana use of 22.1 percent imply an arrest probability of 1.5 percent. Fines and jail time for possessing an ounce of marijuana vary markedly across jurisdictions. While California requires a fine of up to $\$ 100$ but no jail time, Texas requires a fine of up to $\$ 2500$ and up to a year of jail time [NORML 2001]. Because the typical teen drug user will not face jail time, I use a more common $\$ 500$ fine, which is also roughly the populationweighted average of fines in the states in the low-quality THMQ price series. Together these estimates suggest a ratio of pecuniary benefits to costs of about 5.6.

The change in benefits with respect to cohort size comes entirely through the effect on price, $\varepsilon_{S}^{B}$ or -2 . Combining this with our benchmark estimate of the arrest elasticity of drug use of -2 and the ratio of benefits to expected law-related costs suggests that the reduction in drug prices explains about 23 percent of the relationship between youth drug use and cohort size. This estimate is sensitive to the choice of penalties. Using the $\$ 100$ California (New York and Michigan) fine for possession, would explain all of the relationship; using the $\$ 2500$ Texas fine would explain less than 5 percent. Since a teen is unlikely to get the maximum penalty, 23 percent should be treated as a lower bound on the contribution of scale economies to the youth drug usecohort size relationship.

\section{IV.C. Drug Use and Youth Culture: Intergenerational Attitude Transfers, $\Sigma_{x} \varepsilon_{S}^{x} \varepsilon_{x}^{Q}$}

The impact of parental attitudes on teen preferences may also contribute to the cohort size effect. Past work has shown that parental behavior strongly affects directly related youth behaviors (see Case and Katz [1991]). Thus, the high rates of drug use among baby boomers may be directly related to their kids' drug use, implying a shift out in demand concurrent with the increase in cohort size in the 1990 s.

To test the importance of parental attitudes on changes in youth drug use over time, I need to supplement the NHSDA regressions of past month and past year substance use among teens in equation (1) with measures of their parent's substance use. Since the public-use NHSDA does not provide family identifiers, I use the fraction of 37 to 55 years olds within a division and year, who have ever used marijuana, $M J_{37-55 g t}$, cigarettes, 
TABLE VII

The Effect of Lifetime Substance Use among 37-55 Year Olds

on the Probability of Youth Marijuana, Cigarette, AND AlCOHOL Use, NHSDA: 1979-1997

\begin{tabular}{|c|c|c|c|c|}
\hline & \multicolumn{4}{|c|}{ Substance use among $15-19$ year olds } \\
\hline & \multicolumn{2}{|c|}{ Past month use } & \multicolumn{2}{|c|}{ Past year use } \\
\hline & Marijuana & Alcohol & Marijuana & Alcohol \\
\hline \multirow[t]{2}{*}{ ln (Share pop. 15-19) } & .322 & .180 & .318 & .293 \\
\hline & $(.198)$ & $(.256)$ & $(.250)$ & $(.180)$ \\
\hline \multicolumn{5}{|l|}{ Fraction $37-55$ year olds } \\
\hline \multirow[t]{2}{*}{ who used marijuana } & .122 & .179 & .224 & .236 \\
\hline & $(.101)$ & $(.139)$ & $(.109)$ & $(.151)$ \\
\hline \multirow{3}{*}{$\begin{array}{l}\text { Fraction } 37-55 \text { year olds } \\
\quad \text { who smoked }\end{array}$} & & & & \\
\hline & -.048 & -.069 & -.001 & -.100 \\
\hline & $(.066)$ & $(.172)$ & $(.051)$ & $(.155)$ \\
\hline \multicolumn{5}{|l|}{ Fraction $37-55$ year olds } \\
\hline \multirow[t]{2}{*}{ who drank } & .367 & .314 & .332 & .544 \\
\hline & $(.049)$ & $(.161)$ & $(.046)$ & (.136) \\
\hline Mean use & $12.4 \%$ & $36.2 \%$ & $22.1 \%$ & $57.0 \%$ \\
\hline Observations & 40,780 & 40,780 & 40,780 & 40,780 \\
\hline
\end{tabular}

Standard errors in parentheses are cluster-adjusted at the division level. Coefficients on youth use represent the effect of a 1 percent change in the youth share of the population on drug (marijuana, cigarette, or alcohol) participation in the specified interval. The birthrate (or sum of the number of births per person) in division $d 15$ to 19 years earlier is used to instrument for the share of the population 15-19 years old.

The fraction of 37 to 55 year olds using marijuana, cigarette, or alcohol (separately) is measured at the division-year level. Coefficients on the fraction of 37-55 year olds who have ever used marijuana, cigarettes, or alcohol represent the effect of going from no 37 to 55 years old in a youth's division and year using a given substance to all adults in this age group, area, and year using on the youth's own probability of marijuana, cigarette, or alcohol use in the past month or year.

Estimates are based on pooled NHSDA data from 1979-1997. All regressions include controls for the respondent's sex and race, division and year fixed effects, the fraction of 37-55 year olds in that division and year who have ever used marijuana, cigarettes, or alcohol (separately), and division-year unemployment rates. Regressions for 15-19 year olds include age dummies, whereas regressions for those 30 years and older control for the respondent's age and age-squared.

$\mathrm{Cig}_{37-55 g t}$, or alcohol, $A l c_{37-55 g t}$, to proxy for a respondent's parent's use:

$$
\begin{aligned}
\operatorname{Pr}\left(d_{i g t}=1\right)=X_{i g t} \beta+\log ( & \left.s h_{g t}\right) \gamma+M J_{37-55_{g t}} \eta+A l c_{37-55_{g t}} \phi \\
& +\operatorname{Cig}_{37-55_{g t}} \chi+u r_{g t} \pi+\alpha_{g}+\delta_{t}+\varepsilon_{i g t} .
\end{aligned}
$$

I also use 15 to 19 year lagged birthrates to instrument for the youth share.

Table VII shows that higher rates of lifetime marijuana use among 37 to 55 year olds (34.8 percent) within a division translate into higher probability of past month or year marijuana use among teens in the same region. Evaluated at the sample means, 
these estimates suggest that a 10 percent increase in their rates of lifetime marijuana use is associated with a 9 percent increase in past month marijuana use among teens and a 5 percent increase in past year teen use. Marijuana experience among 37 to 55 year olds is also associated with higher cigarette and alcohol use among teens.

Despite the strong link between a teen's marijuana use and the fraction of 37 to 55 year olds who have ever used marijuana in the same division and year, the estimated impact of the youth share on either past month or year marijuana use is little different from the basic instrumental variables estimates in Table I. Including measures of adult substance use reduces the effect of cohort size on youth marijuana use in the past month by only 4 percent and the past year by 8 percent. As suggested by the limited effect of youth cohort size on adult marijuana use (Table Ia, column 4), intergenerational attitude transfers explain little of the relationship between cohort size and youth drug use. ${ }^{24}$ This analysis, however, focuses only on the extent to which parents (or parent-aged adults) shape the preferences of their teens and the baby boomers mediate the "effect" of cohort size on their kids. If peer effects are more important in large cohorts, they may go further in explaining the relationship between youth cohort size and drug use preferences.

\section{CONCLUSIONS}

This paper establishes a large positive relationship between youth cohort size and rates of youth marijuana use. This relationship is not driven solely by national trends. Cohort size within a census division, state, or neighborhood matters for rates of youth involvement with illicit drugs, even when controlling for time effects. I explore various explanations for the relationship: resource strains, scale economies in drug markets, and intergenerational attitude transfers.

I find that reductions in the probability of arrest for drug sales and economies of scale in drug distribution play key roles in this phenomenon. Thicker youth markets provide better networks of information concerning where to "safely" buy and sell

24. This basic conclusion also holds if you consider lifetime use net of past year use among 37 to 55 year olds within a division and year, to purge the measure of current substance use behavior, or if you restrict the parental cohort to 40 to 44 year olds using either measure of use (lifetime or lifetime net of past year). 
drugs, and require a less than proportionate increase in resources to evade the authorities and deliver drugs. The reduction in the unit cost of distributing translates into lower prices of marijuana, which then feeds back to youth use.

As reflected in the negative relationship between cohort size and marijuana prices, the supply channel must dominate the relationship between youth drug use and cohort size. The estimates provided here suggest that it explains at least a quarter and possibly much more of the relationship. Cohort size also affects demand. Drug possession arrest rates for youth decline when cohorts are large, raising the net benefit of consumption. But this mechanism explains less than 10 percent of the relationship. Changes in possession arrests may not, however, be the only factor affecting demand. While not explicitly studied here, cohort size may also affect youth marijuana use through peer multiplier effects. The role of peer effects in explaining the relationship between youth drug use and cohort size is an important area for future research.

UNIVERSITY OF CALIFORNIA, IRVINE

APPENDIX 1:

DesCRIPTIVE StATISTICS FOR NHSDA REgRessions: 1979-1997

\begin{tabular}{lccc}
\hline \hline & $\begin{array}{c}\text { Full } \\
\text { sample }\end{array}$ & $\begin{array}{c}15-19 \\
\text { year olds }\end{array}$ & $\begin{array}{c}\text { 30 years } \\
\text { \& older }\end{array}$ \\
\hline Share pop 15-19 & .071 & - & - \\
& $\begin{array}{c}.007) \\
{[.060, .098]}\end{array}$ & - & - \\
Annual division unemployment rate & 6.71 & & \\
& $(1.72)$ & 49.2 & 41 \\
Percent male & 44.5 & 24.1 & 22.9 \\
Percent black & 23.3 & 17 & 40 \\
Median age & 25 & .226 & .079 \\
Past year marijuana use & .138 & .127 & .044 \\
Past month marijuana use & .078 & .320 & .363 \\
Past year cigarette use & .340 & .565 & .678 \\
Past month cigarette use & .287 & .362 & .533 \\
Past year alcohol use & .617 & 40,889 & 81,207 \\
Past month alcohol use & .464 & 209,559 & \\
Observations & & & \\
\hline \hline
\end{tabular}

Except where indicated, mean is given. Standard deviation appears in parentheses. Youth share of the population is measured at the division-year level for 1979, 1982, 1985, 1988, and 1990-1997. Min and max of youth share of the population appear in brackets. 
APPENDIX 2:

Specification Checks of IV Regressions of Youth Drug Use on Cohort Size

Panel A: Youth share in logs versus levels

NHSDA: Past month marijuana use

\begin{tabular}{lcccc} 
& \multicolumn{2}{c}{$\begin{array}{c}\text { Youth, 15-19 years old } \\
\text { Mean use }=12.4 \%\end{array}$} & \multicolumn{2}{c}{$\begin{array}{c}\text { Adult, 30 years \& older } \\
\text { Mean use }=53.0 \%\end{array}$} \\
\hline Youth share & .334 & 3.22 & .070 & .713 \\
& $(.209)$ & $(2.66)$ & $(.061)$ & $(.841)$ \\
Observations & 40,780 & 40,780 & 81,117 & 81,117 \\
Specification & Logs & Levels & Logs & Levels \\
\hline
\end{tabular}

Panel B: Monitoring the future 1975-1999 \& youth share in logs versus levels

MTF: Marijuana use among high school seniors

\begin{tabular}{lcccc} 
& \multicolumn{2}{c}{ Past month } & \multicolumn{2}{c}{ Past year } \\
& \multicolumn{2}{c}{ Mean use $=25 \%$} & \multicolumn{2}{c}{ Mean use $=39 \%$} \\
\hline Youth share & .580 & 6.41 & .676 & 7.35 \\
& $(.149)$ & $(2.60)$ & $(.141)$ & $(2.76)$ \\
Observations & 307,902 & 307,902 & 308,431 & 308,431 \\
Specification & Logs & Levels & Logs & Levels \\
\hline
\end{tabular}

Panel C: Absolute growth in or size of youth population

NHSDA: Past month marijuana use

$$
\text { Youth, 15-19 years old Adult, } 30 \text { years \& older }
$$

\begin{tabular}{lcccc}
\hline Youth & & & \\
$\quad$ population & .321 & $8.82 \times 10^{-8}$ & .102 & $1.73 \times 10^{-8}$ \\
& $(.218)$ & $\left(4.4 \times 10^{-8}\right)$ & $(.089)$ & $\left(3.41 \times 10^{-8}\right)$ \\
Total & & & \\
$\quad$ population & -.282 & $-3.05 \times 10^{-9}$ & -.197 & $-3.08 \times 10^{-9}$ \\
& $(.307)$ & $\left(5.58 \times 10^{-9}\right)$ & $(.142)$ & $\left(2.99 \times 10^{-9}\right)$ \\
Specification & Logs & Levels & Logs & Levels \\
\hline \hline
\end{tabular}

Standard errors are in parentheses. In Panels A, C, and D, they are clustered at the division level. In Panel B, which uses Monitoring the Future (MTF) data, they are clustered at the region (4) level.

Panel A and C estimates are based on pooled NHSDA data from 1979-1997. NHSDA regressions include controls for the respondent's sex and race as well as division and year fixed effects and division-year unemployment rates. Regressions for 15-19 year olds include age dummies, whereas regressions for those 30 years and older control for the respondent's age and age-squared.

Panel B estimates are based on pooled MTF data from 1975-1999. MTF regressions control for respondent's sex, race, whether she is over 18, urbanicity, parent's education, number of siblings, marital status, type of high school, work status, and church attendance as well as region and year fixed effects.

The birthrate (or sum of the number of births per person) in division $d$ (for NHSDA) or region $r$ (for MTF) 15 to 19 years earlier is used to instrument for the population 15-19 years old. 
APPENDIX 3:

Descriptive Statistics for AdD Health Regressions

\begin{tabular}{lc}
\hline \hline & Full restricted use sample \\
\hline Percent male & 49.4 \\
Percent black & 23.2 \\
Mean age & 15.2 \\
Number of siblings in household & 1.46 \\
& $(1.23)$ \\
Age of biological mother & 41.2 \\
& $(5.55)$ \\
Family income & 45700 \\
& $(51600)$ \\
Number of students in school & 1213 \\
& $(831)$ \\
Ever used marijuana & 28.6 \\
Past month marijuana use & 14.4 \\
Suicidal thoughts in past year & 13.4 \\
Suicidal attempts in past year & 3.89 \\
Medically treated suicide attempt in past year & 0.96 \\
Parent lives in neighborhood for lower teen drug use & 56.0 \\
Parent lives in neighborhood for lower crime & 50.0 \\
Parent lives in neighborhood because it is affordable & 50.7 \\
Observations & 20745 \\
\hline \hline
\end{tabular}

Standard deviations of continuous variables are given in parentheses.

APPENDIX 4:

Description of Add Health Data Used in Analysis of Teen Drug Use

\begin{tabular}{|c|c|c|}
\hline Variable & Respondent & Question \\
\hline $\begin{array}{l}\text { Parent lives in } \\
\text { neighborhood for } \\
\text { lower teen drug use }\end{array}$ & Parent & $\begin{array}{l}\text { You live here because there is less drug use } \\
\text { and other illegal activity by adolescents } \\
\text { in this neighborhood (Y/N). }\end{array}$ \\
\hline $\begin{array}{l}\text { Parent lives in } \\
\text { neighborhood for } \\
\text { lower crime }\end{array}$ & Parent & $\begin{array}{l}\text { You live here because there is less crime in } \\
\text { this neighborhood than there is in other } \\
\text { neighborhoods }(\mathrm{Y} / \mathrm{N}) \text {. }\end{array}$ \\
\hline $\begin{array}{l}\text { Drug problem in the } \\
\text { neighborhood }\end{array}$ & Parent & $\begin{array}{l}\text { In this neighborhood, how big a problem } \\
\text { are drug dealers and drug users? (no, } \\
\text { small, big problem) }\end{array}$ \\
\hline $\begin{array}{l}\text { Parent drinks } \\
\text { heavily }\end{array}$ & Parent & $\begin{array}{l}\text { How often in the last month have you had } \\
\text { five or more drinks on one occasion? ( } 4 \text { or } \\
\text { more times coded as heavy drinking) }\end{array}$ \\
\hline Parent smokes & Parent & Do you smoke? \\
\hline $\begin{array}{l}\text { Suicidal thoughts in } \\
\text { past year }\end{array}$ & Teen & $\begin{array}{l}\text { During the past } 12 \text { months, did you ever } \\
\text { seriously think about committing suicide? }\end{array}$ \\
\hline $\begin{array}{l}\text { Suicidal attempts in } \\
\text { past year }\end{array}$ & Teen & $\begin{array}{l}\text { During the past } 12 \text { months, how many } \\
\text { times did you actually attempt suicide? } \\
\text { (coded as } 0,1 \text { in regressions) }\end{array}$ \\
\hline $\begin{array}{l}\text { Medically treated } \\
\text { suicide attempt in } \\
\text { past year }\end{array}$ & Teen & $\begin{array}{l}\text { Did any attempt result in an injury, } \\
\text { poisoning, or overdose that had to be } \\
\text { treated by a doctor or nurse? }\end{array}$ \\
\hline
\end{tabular}




\section{REFERENCES}

Bertrand, Marianne, Esther Duflo, and Sendhil Mullainathan, "How Much Should We Trust Differences-in-Differences Estimates?" Quarterly Journal of Economics, CXIX (2004), 249-275.

Bound, John, and Sarah Turner, "Cohort Crowding: How Resources Affect Collegiate Attainment," PSC Research Report 04-557, April 2004.

Case, Anne, and Lawrence Katz, "The Company You Keep: The Effects of Family and Neighborhood on Disadvantaged Youths," NBER working paper No. 3705, 1991.

Caulkins, Jonathan, "Comment on the Use of the STRIDE Database as a Source of Price Data for Illegal Drugs?" Journal of the American Statistical Association, XCVI (2001), 1263-1264.

Chaloupka, Frank, Michael Grossman, and John Tauras, "The Demand for Cocaine and Marijuana by Youth," in The Economic Analysis of Substance Use and Abuse, F. Chaloupka, M. Grossman, et al., eds. (Chicago: University of Chicago Press, 1999), pp. 133-155.

Easterlin, Richard, "What Will 1984 be Like? Socioeconomic Implications of Recent Twists in Age Structure," Demography, XV (1978), 397-421.

Farrelly, Matthew, Jeremy Bray, Gary Zarkin, et al., "The Effects of Prices and Policies on the Demand for Marijuana," NBER working paper No. 6940, 1999.

Frank, Richard, "Drugs of Abuse: Data Collection Systems of the DEA and Recent Trends," Journal of Analytical Toxicology, XI (1987), 237-241.

Glaeser, Edward, and Bruce Sacerdote, "Why Is There More Crime in Cities?" Journal of Political Economy, CVII (1999), S225-S256.

Glassner, Barry, and Julia Loughlin, Drugs in Adolescent Worlds: Burnouts to Straights (London: The Macmillan Press, 1987).

Gruber, Jonathan, "Introduction," in Risky Behavior among Youths: An Economic Analysis, J. Gruber, ed. (Chicago: University of Chicago Press, 2001).

Harrison, Lana, "Trends and Patterns of Illicit Drug Use in the USA: Implications for Policy," International Journal of Drug Policy, VI (1995), 113-127.

High Times, "Trans-High Market Quotations" (New York: Trans-High Corporation Press, various issues, 1974-2000).

Horowitz, Joel, "Should the DEA's STRIDE Data Be Used for Economic Analyses of Markets for Illegal Drugs?" Journal of the American Statistical Association, XCVI (2001), 1254-1262.

Jessor, Kichard, ed., New Perspectives on Adolescent Risk Behavior (New York: Cambridge University Press, 1998).

Johnson, Robert, Dean Gerstein, Rashna Ghadialy, et al., Trends in the Incidence of Drug Use in the United States, 1919-1992 (Washington, DC: Department of Health and Human Services, Pub No. (SMA) 96-3076, 1996).

Johnston, Lloyd, Patrick O'Malley, and Jerald Bachman, Monitoring the Future National Survey Results on Drug Use, 1975-1999. Volume I: Secondary School Students (Bethesda, MD: National Institute on Drug Abuse (No. 00-4802), 2000).

Levitt, Steven, "The Limited Role of Changing Age Structure in Explaining Aggregate Crime Rates," Criminology, XXXVII (1999), 581-597.

"Why Do Increased Arrest Rates Appear to Reduce Crime: Deterrence, Incapacitation, or Measurement Error?" Economic Inquiry, XXXVI (1998), 353-372.

National Household Survey on Drug Abuse (NHSDA), Summary of findings from the National Household Survey on Drug Abuse (Rockville, MD: Department of Health and Human Services, Office of Applied Studies, 1998).

National Organization for the Reform of Marijuana Laws. State Guide to Marijuana Penalties, http: / /www.norml.org/index.cfm?Group_ID=4516, 2001.

O'Brien, Robert, "Relative Cohort Size and Age-specific Crime Rates," Criminology, XXVII (1987), 57-77.

Pacula, Rosalie Liccardo, Michael Grossman, et al., "Marijuana and Youth," in Risky Behavior Among Youths: An Economic Analysis, J. Gruber, ed. (Chicago: University of Chicago Press, 2001).

Padilla, Felix, The Gang as an American Enterprise (New Brunswick, NJ: Rutgers University Press, 1992). 
Poterba, James, "Demographic Structure and the Political Economy of Public Education," Journal of Policy Analysis and Management, XVI (1997), 48-66.

Ruhm, Christopher, "Are Recessions Good for Your Health?" Quarterly Journal of Economics, CXV (2000), 617-650.

Schneider, Victoria, and Brian Wiersema, "Limits and Use of the Uniform Crime Reports," in Measuring Crime: Large-Scale, Long Range Efforts, Doris Layton Mackenzie, et al. eds. (Albany, NY: State University of New York Press, 1990).

Shimer, Robert, "The Impact of Young Workers on the Labor Market," Quarterly Journal of Economics, CXVI (2001), 969-1007.

Steffensmeier, Darrel, Caty Streifel, and Miles Harer, "Relative Cohort Size and Youth Crime in the United States, 1953-1984," American Sociological Review, LII (1987), 702-710. 